\title{
Røyking er enda farligere enn hittil antatt
}

\begin{abstract}
Tobakksrøyking gir overdødelighet ved en rekke tilstander som tidligere ikke har vært forbundet med røyking. Dette viser en stor epidemiologisk studie fra USA.
\end{abstract}

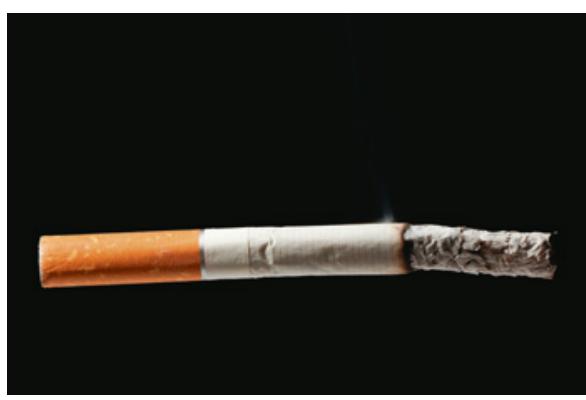

Illustrasjonsfoto: Scanpix
Det er velkjent at røyking øker risikoen for kardiovaskulær sykdom, diabetes, kols og flere kreftformer. I en amerikansk prospektiv epidemiologisk multisenterstudie ble nær en million menn og kvinner over 55 år fulgt gjennom 11 år (1). Hele $17 \%$ av overdødeligheten ved røyking var forårsaket av tilstander som tidligere ikke er vist å være forbundet med røyking. Dette gjaldt bl.a. nyresvikt (relativ risiko 2,0;95\% KI 1,7-2,3), tarmiskemi $(6,0 ; 95 \%$ KI 4,5-8,1), hypertensiv hjertesykdom $(2,4 ; 95 \% \mathrm{KI} 1,9-3,0)$ og en rekke ulike luftveissykdommer. I tillegg var det en antydning til sammenheng mellom røyking og prostatakreft og brystkreft. Blant tidligere røykere sank den relative risikoen for hver av disse sykdommene med antall år etter røykeslutt.

- Det er interessant hvordan listen over sykdommer forårsaket av røyking stadig øker, sier Tore Sanner ved Radiumhospitalet. - I 1964 mente den amerikanske helsedirektøren at røyking var årsak til lungekreft blant menn og «mistenkt» som årsak til lungekreft hos kvinner. Denne studien viser at listen ennå ikke er fullstendig og at det $\mathrm{i}$ de nærmeste år vil komme til nye tilstander som må tas i betraktning for å lage korrekte estimater av sykelighet, overdødelighet og helsekostnader forårsaket av tobakk, sier Sanner.

\section{Inge Rasmus Groote}

Tidsskriftet

\section{Litteratur}

1. Carter BD, Abnet CC, Feskanich D et al. Smoking and mortality-beyond established causes. N Engl J Med 2015; 372: 631-40.

\section{Nyoppdaget reguleringsmekanisme for trombocytter}

\section{En nyoppdaget mekanisme for trombocyttregulering kan forklare flere kliniske fenomener.}

Trombopoietin, produsert i leveren, driver utviklingen fra stamcelle til megakaryocytt og stimulerer produksjonen av trombocytter i beinmargen. Man mener at trombopoietinnivået $\mathrm{i}$ blod og beinmarg reguleres ved at megakaryocytter og trombocytter tar opp og bryter ned trombopoietin. Store mengder megakaryocytter og trombocytter vil da føre til at trombopoietinmengden reduseres og at det dannes færre trombocytter, slik behovet tilsier. En nyoppdaget reguleringsmekanisme for trombocyttproduksjon er omtalt $\mathrm{i}$ Nature Medicine (1).

Trombocytter vil etter hvert miste sialinsyre ytterst på overflateglykaner, slik at galaktose eksponeres. Når trombocyttene har sirkulert i rundt ti dager, vil galaktoseeksponeringen stimulere en reseptor (Ashwell-Morell-reseptor, AMR) på blodsiden av hepatocyttene til endocytose av trombocyttene. Dette stimulerer JAK-STAT-signalsystemet i hepatocyttene til økt trombopoietin-produksjon. I transgene mus, med defekt AMR-reseptor, hadde trombocyttene økt levetid, men megakaryocyttmengden var redusert. I mus som manglet sialinsyre på overflateglykanene, hadde trombocyttene kort levetid, og det var økt megakaryocyttmengde i beinmargen. Serumnivåene av trombopoietin var $\mathrm{i}$ disse tilfellene forandret motsatt av hva den gamle regule- ringsmekanismen forutsa. Opptak av trombocytter uten sialinsyre $\mathrm{i}$ en human levercellelinje stimulerte også JAK-STAT-systemet.

- Denne studien avdekker en helt ny mekanisme for regulering av blodplateproduksjonen, og som synes å kunne forklare flere tidligere uforklarte kliniske observasjoner, sier professor Geir E. Tjønnfjord ved Oslo universitetssykehus.

- Trombocytopeni er en velkjent bivirkning ved behandling med JAK1/JAK2-hemmeren ruxolitinib, noe som nå synes å ha fått en god forklaring. Ved immunologisk trombocytopeni er trombopoietinnivåene overraskende lave og ved essensiell trombocytose overraskende høye. Disse observasjonene kan nå lettere forklares. Trombocytosen som regelmessig ses ved kronisk inflammasjon, har også fått en forklaring, ettersom IL-6/IL6R-signalering har likheter med AMR-signaleringskaskaden og fører til JAK1/STAT3stimulering, påpeker Tjønnfjord.

\section{Haakon B. Benestad}

Universitetet i Oslo

\section{Litteratur}

1. Grozovsky R, Begonja AJ, Liu K et al. The AshwellMorell receptor regulates hepatic thrombopoietin production via JAK2-STAT3 signaling. Nat Med 2015; $21: 47-54$

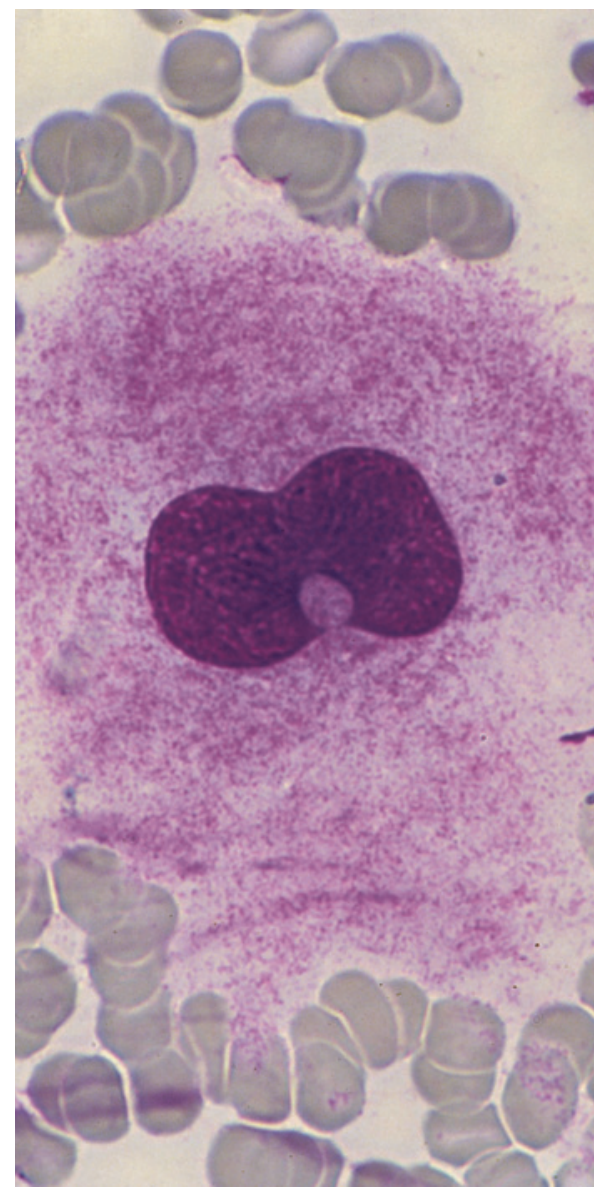

Illustrasjonsfoto: Science Photo Library 